\title{
Study on Group Characteristics and the Improvement of Employment Ability of Students with Poor Families and Poor Employment Ability in Agricultural Universities of Jilin Province
}

\author{
Zhao Yunchang ${ }^{1, a}$, Yue Yongchao ${ }^{2, b}$ \\ ${ }^{1}$ Jilin Agricultural University, Changchun Jilin 130118,China; \\ ${ }^{2}$ No. 156 Middle School of Changchun, Changchun Jilin 130604, China. \\ a360023251@qq.com, b260818740 @qq.com
}

Keywords: "supply-side" reform; precise help; double poor students.

\begin{abstract}
Under the background of supply-side reform and economic development in China, many human resources are needed, but the difficulty of college graduates in hunting jobs becomes more and more serious, especially the students with poor family and poor employment ability. They are at a disadvantage in the competition for jobs, and need to get precise employment assistance. This paper tries to explore ways and means to improve the employment ability of "double poor" students from the perspective of supply-side reform.
\end{abstract}

\section{The Current Problems in the Help of the "Double Poor Students" Employment}

\subsection{Supply-side problems in colleges and universities}

With the increase of the number of college graduates and people to be employed in China year after year, employment is becoming more and more difficult. At the same time, small and medium enterprises, especially the emerging industry need to hire the right people urgently, but recruitment is still difficult to fulfil. This "dilemma" coexists for a long time, reflecting that the employment of college graduates and even the whole cause of employment in China is not the problem in demand side, not a lack of effective demand, but the problem in supply side. ${ }^{[1]}$ Two reasons for the expansion enrolment of colleges and the fact that the process of personnel training is out of line with the actual needs of social and economic development, lead to the university "overcapacity." Colleges and universities need "supply side" reform urgently, to "produce" marketable "best-selling products" to promote economic and university development to contribute to the national economic "supply side" reform.

\subsection{Inaccuracy in the Employment Help Connotation of "Double Poor Students"}

First, responsibility subjects of implementing employment help are ambiguous. In general, they are relevant government departments, but not identified clearly; second, students with employment difficulties are considered as those with family financial difficulties, and thus the objects are unclear. And only those with financial difficulties get employment assistance. Third, objects of employment help are generalized. The government requires the adoption of policies and measures to promote the employment of college students as a whole, but there is no precision to the "double poor students". The subject sand objects are relatively vague, making it difficult to implement the national relevant policies. ${ }^{[2]}$ 


\subsection{Failure in Forming a Precise Employment Help in the Whole Society}

First, the government and universities as the subjects of implementing employment help failed to combine society with families and students themselves to form a precise employment help mechanism of assistance and self-help. A joint force is not formed. Second, it lacks the normalization of job markets. Unfair employment via interpersonal relationships still exists, which is not conducive to "double poor students" employment. The third reason is concerned with families. In such families, parents are mostly vulnerable group in the society and can't provide good growth environment sand social relations to help employment for their children, resulting in self-esteem or interpersonal barriers and other psychological problems of such students, leading to a vicious cycle of employment difficulties. Fourth, some of the "double poor students" in the job hunting have high expectations, bent on the position with high income and good welfare. Such job expectations are not matched with the recognition of the graduates of the society, which directly affects the success rate of employment and the quality of employment.

\section{Methods to Help "Double Poor Students" Enhance Their Employment Ability Precisely}

\subsection{The Government Promoting the School-enterprise Joint, Building "online, offline" "Double Poor Students" Employment Platforms to Solve the Problem of "Supply Side" in Colleges and Universities.}

(1) Promoting school-enterprise cooperation and taking order-based training

First, pay attention to internships, fulfil post practice and improve the relevance of personnel training so that college graduate's employment and social needs are connected seamlessly. Second, encourage enterprises to actively assume social responsibility, give priority to use "double poor students" and the government should give the corresponding tax relief and preferential policies.

(2) Relying on various social organizations to provide accurate employment information for the "double poor students", reducing job hunting costs and improving job hunting rates

First, encourage all kinds of Poverty Alleviation Foundation to play a role, to ensure that the "double poor students" can complete their studies and employment successfully. Second, civil affairs departments at all levels and the community provide legal aid, subsistence allowances, posttracking services and so on, working together to help "double poor students" employment.

(3) Constructing "Internet + precision employment" mode and docking "online, offline" two platforms precisely. Make use of employment network and develop mobile employment APP to combine information database of "double poor students" graduates with that of staff vacancy. Seize two sides of "supply" and "demand", and "school" and "social needs" to create "double poor student's employment Internet plus" marketing model, recommending their precise employment.

\subsection{Exploring the long-term mechanism to help "double poor students" employment}

As a special group after the higher education investment, college graduates face with more unemployment pressure than the common people. Therefore, the government and society should establish a related relief system. ${ }^{[3]}$

(1) Setting up "double poor students" employment help fund. First, the government should increase the investment of special funds and make clear the proportion and quota that school employment funds account for in school education funding. Second, establish funds with the help of alumni, social enterprises and individuals.

(2) Establishing tracking help system for "double poor students" after graduation

First, give a certain amount of living subsidies to the "double poor students" who did not find jobs to reduce their economic burden and psychological pressure. Second, relying on enterprises, "double poor students" are trained for employment and thus enterprises can get human resources to solve the "double poor students" employment. Third, colleges and universities establish the information base of "double poor students" unemployed, train them with employment skills and 
professional knowledge and provide employment information to achieve "constant care and service even after graduation", ${ }^{[4]}$ until recommended successful employment for them.

(3) Playing the role of subjects of "double poor students" and their families and establishing help linkage and feedback mechanism

First, establish the linkage feedback mechanism of parents and colleges. When parents find that students encountered problems they can resolve in job hunting process, they should give the feedback to the school in a timely manner to discuss countermeasures to help students out of employment difficulties in time. Second, teach "double poor students" reasonable assessment of positioning their own ability and employment direction. Through the workplace experience to find their own gaps, they should constantly improve their own knowledge structure and overall quality. The third is to cultivate their positive and optimistic attitudes towards life. When they encounter frustration and failure in the employment process, they should analyze the reasons, sum up experience and seek help from the teacher timely to maintain a good job mentality, combine the reality with their own conditions and go to the place where the country needs us and to achieve selfsocial value.

\subsection{Colleges and Universities Helping "Double Poor Students" Precisely with "One Person One Policy"}

(1) Adjusting the personnel training program, deepening the teaching reform, and strengthening the internship and practice

First, adhere to the social needs-orientation, follow the job market demands closely, adjust professional settings and enrolment plan timely, and deepen the teaching, curriculum reform to achieve the goal of close docking of personnel training and social needs. Second, build employment and internship bases with the enterprise. Through the talent training model of combining work with study, the students are sent to all types of business lines to accept the correct professional awareness in the actual working environment and apply their professional knowledge into business production to enhance the ability to transform knowledge, practical ability and professional quality.

(2) Determining the help object precisely

First, a comprehensive screening is conducted through the self-evaluations and the evaluations of teachers and others about graduates' employment psychology, employment skills, academic performance and other personal factors to establish the information base of "double poor students". Second, based on the national precision poverty alleviation policy docking, poor families, zero employment families, preferential families, rural and urban poor families, disabled college students identified by all levels of poverty alleviation institutions are brought into the information base of "double Poor students ". Third, dynamic management is applied to those in the information data of "double poor students" with "one person one policy". Students with successful employment are removed from the repository.

(3) "One to one" precision design training program.

First, enhance the teaching of practice for students with poor hands-on ability to strengthen practi cal ability and vocational skills training. Second, recommend students with low language skills and poor writing ability to participate in "double poor students" training and vocational training camp. $\mathrm{T}$ hird, carry out ritual lectures for the poor image of the students to improve the external image and th e interview plus points. Fourth, help "double poor students" identify and grasp the employment opp ortunities accurately. According to the actual situation of "double poor students", recommended the $\mathrm{m}$ to participate in the western plan, three supports and one assistance plan, specially contracted tea chers plan, enlistment and other places where our country needed employment most.

(4) Establishing a precise "double poor students" psychological assistance mechanism. Set up psychological assistance files and carry out actively psychological counselling and psychological assistance and the intervention to ease their sensitivity and inferiority and other negative emotions timely. Encourage them to participate in collective activities, improve their communication, coordination, cooperation and other professional capacity. Make the most of new media to publish a 
brief case of success and "soul chicken soup" information to guide the formation of positive attitudes.

\section{Conclusion}

The precision help of "double poor students" employment is a systematic project, which needs multi-party coordination from nation, society, university, students and families. The nation should increase the financial investment, so that the employment of college graduates can be continued to promote and only solving the employment of vulnerable groups can economic development be promoted and win-win situation be achieved; colleges and universities as "double poor students" employment ability training base should pay attention to the multiple training of core competitiveness such as their professional ability, comprehensive quality and so on; the whole society should pay attention to problems of "double poor students" employment and especially the employing units, they should provide fair employment opportunities for "double poor students"; "double poor students" should identify themselves accurately, set a reasonable goal of employment and take self-confidence and optimistic attitudes to participate in the fierce employment competition.

\section{Acknowledgments}

This article is the research result of the "13th Five-Year Plan " social science research project (employment special) of Jilin Provincial Department of Education, "Research and Practice on Group Characteristics and the Improvement of Employment Ability of Students with Poor Families and Poor Employment Ability in Agricultural Universities in Jilin Province"(project number: JJKH20170335JY); The stage research result of Education Science in Jilin Province "13th FiveYear Plan " 2017 annual project " Research and Practice on Improving the Employment Ability of "Double Poor Students" with Precise Help in Colleges and Universities Based on " Supply Side "Reform (project number:GH170257); The research result of Education Science in Jilin Province "13th Five-Year Plan " 2016 annual key project " Research on Cultivating Innovative Ability and Practical Ability of Students in Agricultural Universities" (approval number: ZD16036).The stage research result of 2017 annual higher education research project of Higher Education Institute of Jilin Province "Research on Curriculum Construction of Innovation and Entrepreneurship of College Students in Agriculture-related Universities in Jilin Province " (project number: JGJX2017D44).

\section{References}

[1]. Wang Meili. Study on Precision Employment Services in Colleges and Universities in the Era of Big Data [J]. Ideological and Theoretical Education, 2016 (6):87-89.

[2]. Wu Songqiang. Perfecting the Employment Assistance System for College Graduates with Difficulty in Employment [J]. Ideological and Theoretical Education, 2014 (4): 63-67.

[3]. Jiang Dong, Shen Yi. Study on Employment Assistance of Graduates of Family Financial Difficulties in Colleges and Universities [J]. Modern Education Management, 2010 (5): 122-125.

[4]. Wang Meili. Study on Precision Employment Services in Colleges and Universities in the Era of Big Data [J]. Ideological and Theoretical Education, 2016 (6):87-89. 